\title{
Preventive Measures Reducing the Risk of Occurrence of Competence Gaps in Terms Of Emotional Intelligence of Successors in Family Businesses in Poland
}

\author{
Mariola DŹWIGOt-BAROSZ, PhD \\ mariola.dzwigol-barosz@polsl.pl \\ Silesian University of Technology, Faculty of Organization and Management, Poland;
}

\begin{abstract}
The main aim of the research was to identify preventive measures that would minimise the risk of occurrence of competence gaps in terms of emotional intelligence of successors in family businesses. The article contains issues related to emotional intelligence of successors in contemporary family businesses. The author underlined complexity and ambiguity of a process aimed at elaborating a set of successors' competencies necessary to run family businesses, which has been a subject of research of many representatives of the academic community (in the field of psychology and management). The main aim of the article was to emphasize the importance of competencies of successors in contemporary family businesses, with particular emphasis on competences related to emotional intelligence, which constitute an important part of their competences. It was proved by results achieved by other researchers, as mentioned herein, combined with the author's own research. The article described a notion of successors' emotional education, with particular importance of the role of parents in the early years of their children, when the children are learning how to manage their emotions and relationships. The author also indicated sample actions and methods destined to enhance competencies within the scope of emotional intelligence, along with benefits derived from their application. The role of the self-development method was emphasized, which is based on systematic work on the development of personal competences and is a method that supports the strategy of family businesses because it leads to a change in attitudes in terms of quality.
\end{abstract}

Keywords: family businesses, successor, competences, emotional intelligence.

\section{Introduction}

The majority of Polish family enterprises founded in the 90's are faced with a decision to start a succession process. Succession is connected not only with taking over ownership and power, but above all, with responsibility for business management and the people employed in it. Meeting such requirements is possible with the assumption that future owners have broad management competences. Therefore, the competencies held will be the decisive resource of people being evaluated, and the results will depend on the choice between family members and often between managers from outside the family.

The efficient management of family enterprises requires successors to implement both: economic indicators and care for interpersonal relationships. The broadly understood skills in the field of interpersonal relationships are mainly in the area of competence in the area of emotional intelligence, which gives grounds for seeking answers to the following questions:

- which of the competencies in the field of emotional intelligence determine a successful process of succession?

- what competence gaps are present in potential successors of Polish enterprises?

- what preventive measures can be implemented to avoid the occurrence of emotional competence gaps in the future?

An attempt to answer the above questions was made in this article, in which the assumption was made that emotional intelligence constitutes an important part of the successor's competences and can be developed as a result of the activity from the youngest childhood.

Emotional Intelligence Competences - The Importance In The Process Of Succession

Emotional intelligence plays a major role in human life, not only in relation to private life, but also to professional life. It affects the development of own potential, facilitates the development of positive relationships between people and the establishment of boundaries in relations between them.

Emotional intelligence means personal competences of people, which include: the ability to recognize emotional states of their own, emotional states of other people, the ability to use their own emotions and the ability to deal with the emotions of other people (Mikołajewska, Mikołajewski, 2013, p. 3). ). Emotional intelligence also includes the ability to regulate and control one's mood. Understanding and proper use of emotions plays an important role in human life.

The precursor of emotional intelligence research is H. Gardner, who in studies published in 1989 indicated as two components of emotional intelligence: intrapersonal intelligence and interpersonal intelligence (also called as social intelligence) (Gardner, 1989). The first one refers to the ability to understand and control one's emotions, while the other includes the ability to understand and deal with other people.

According to the authors E, Mikołajewska and D. Mikołajewski, competences in the area of emotional intelligence include: (Mikołajewska, Mikołajewski, 2013, p. 3).

- the ability to use own emotions, which includes controlling and regulating one's mood,

- the ability to recognize your own emotional states and emotional states of other people,

- the ability to interpret, understand and use the emotions of other people

The main results of the research presented in the report entitled "Competencies of the future in the family businesses 2017" clearly indicate the significance of social competences in family enterprises. All surveyed family enterprises confirm that social intelligence is the most desirable competence of the future. In addition, up to $3 / 4$ of the surveyed entrepreneurs expressed the need and readiness to develop competences in this area (Raport, 2017, s. 15).

The significance of emotional intelligence in family enterprises is also confirmed by studies conducted by E. Więcek - Janek and A. Hadryś - Nowak. From among 20 important competences of successors, as many as 11 relate to emotional intelligence. Belong to them: (Więcek-Janka, and Hadryś-Nowak, 2016, p. 61-72)

The current issue and full text archive of this journal is available at http://jraspublications.org/index.php/JRAS/issue/archive Journal of Research in Administrative Sciences (JRAS) VIII (II), 1-5, ISSN: 2664-2433 
- ambition,

- accuracy,

- commitment,

- resourcefulness,

- courage,

- motivation,

- diligence,

- firmness,

- resistance to stress,

- communication skills,

- organizational skills.

The necessity for the successors to possess psychological and social skills necessary in the succession process is also emphasized by L. Weroniczak, who assigns particular importance to the features shown in Figure 1.

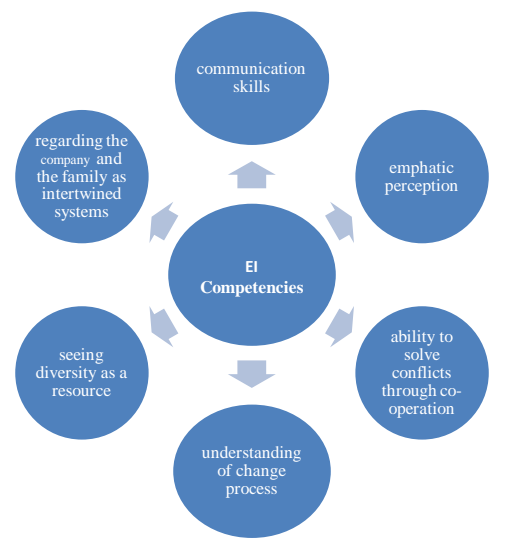

Figure 1. Significant competences in the field of emotional intelligence of successors. Weroniczak, 2012, p. 81.

The key tasks of today's managers include shaping the organizational culture, setting development trends and motivating employees to work. For this reason, competence in the area of emotional intelligence is gaining importance. Undertaking activities to build team stability by creating an atmosphere based on empathy is one of the key competences of modern managers. These managers, who are able to maintain and motivate their teams, are able to continue and expand their business activities. Therefore, family enterprises that plan the process of succession should pay special attention to the competence profiles of successors, including also the competences in the area of emotional intelligence.

Developing Emotional Intelligence of Successors

Many authors claim that the best way to acquire emotional competences is to take action on the impact of supporting person-person relationships, such as e.g. mother - child, teacher student or relationships between individuals and groups, e.g. teacher - class team (Brzezińska, 2000, pp. 224-257, Shapiro, 1999).

In the process of developing emotional intelligence one should focus on both: personal and social aspects, taking into account the fact that competences from this area are already shaped during childhood. Therefore, the whole process includes the development of basic, social and emotional competences (CASEL ..., 2002; Denham, and Weissberg, 2003), which is often done by observing parents or other people who play a significant role in the child's life. This in turn creates the conditions for learning how to manage relationships and emotions. The development of emotional intelligence can, however, take place through numerous methods, regardless of the experience gained during childhood. Psychologist and expert at the Institute of Family Business - W. Machalica is the author of various training, programs and workshops developing emotional intelligence in the field of intergenerational relations. The author proposes the use of numerous tools that lead to the following benefits (Figure 2).

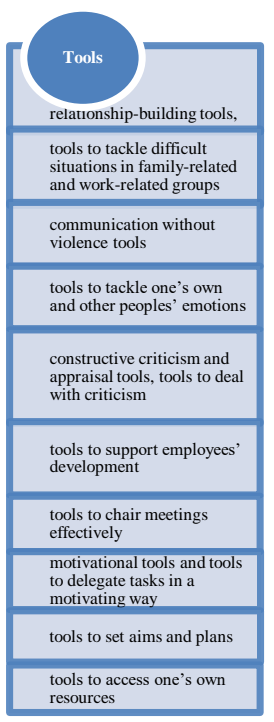
Volume VIII, Issue II, 2019, 1-5

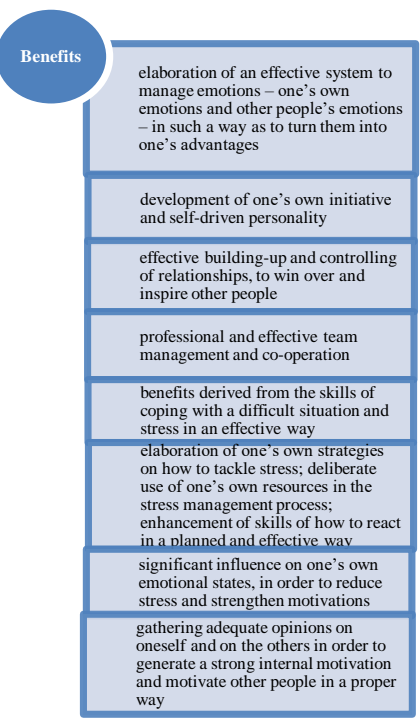

Figure 2. Tools of enhancement emotional intelligence and benefits resulting from their use Machalica, 2017.

The same author in her other publication (Machalica, 2012, p.110) attributes a special role to the method of selfdevelopment, understood as a systematic work on the development of own competences. Self-development is a key element of supporting family businesses by ensuring a change in attitudes in the qualitative dimension on three levels (Figure 3).

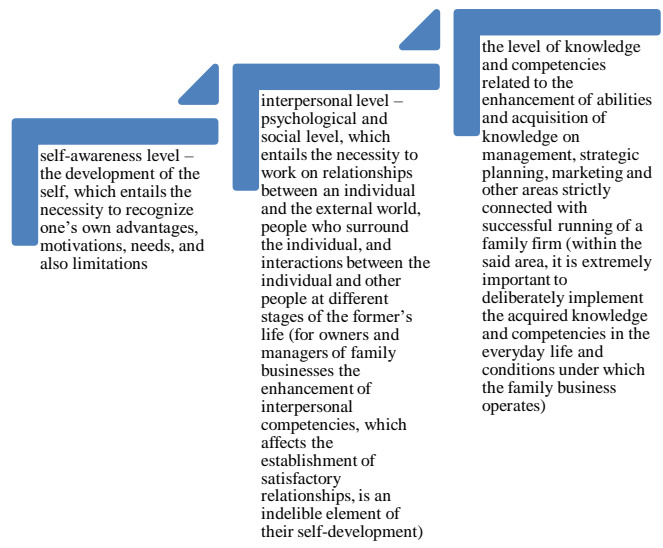

Figure 3. Three levels of self-development. Machalica, 2012

Unfortunately, there is still a deficit of institutions supporting the preparation of future CEOs to include family enterprises in the future. In consequence, this leads to a situation in which awareness related to the complexity and specificity of succession processes is at a much lower level than in countries in which they operate, for example: specialized "survival schools for young, future managers" or the scientific Organization of the Young President. As emphasized by $Ł$. Sułkowski and A. Mariański (Sułkowski, and Marianski, 2009, p. 40) with the support of such institutions, future leaders have the opportunity to participate in competitive workshops or numerous team building exercises that teach such values as: courage, insight, analytical skills and interaction skills.

Research methodics as to preventive measures reducing the risk of occurrence of competence gaps in terms of emotional intelligence of successors in family businesses in Poland The research was carried out in the period: February - December 2016 and included territorially the Silesian Province in Poland. Within the scope of the research, aimed at identifying preventive measures reducing the risk of occurrence of competence gaps in terms of emotional intelligence of successors in family 
businesses, a method of expert group evaluation was applied, with the use of individual, partly-structured interviews.

The group of experts were selected by means of an expert's competence co-efficient $\left(\mathrm{K}_{\mathrm{k}}\right)$. The coefficient takes into account their experience and knowledge in the subject under study (formula 1).

$$
K_{k}=\frac{k_{z}+k_{a}}{2}
$$

where:

$\mathrm{K}_{\mathrm{k}}$ - co-efficient of experts' competence,

$\mathrm{k}_{\mathrm{z}}$ - co-efficient of experts' familiarity with a given issue,

$\mathrm{k}_{\mathrm{a}}$ - co-efficient of argumentation.

Source: Męczyńska, 2007.

A threshold value of the co-efficient was adopted in the test $\rho=$ 0.8 . This means that if a given respondent has obtained a value greater than or equal to the threshold value $(\mathrm{Kk} \geq \rho)$, then the respondent is appointed as an expert and their answers are subject to analysis.

Out of 25 respondents, 16 experts were selected for the purpose of the study.

The people, subject to partly structured, individual, in-depth interviews, were:

- Psychologists who are also coaches and personal development trainers $-44 \%$ of the experts,

- psychology lecturers at higher education institutions ${ }^{1}$ who are psychology practitioners (therapists and coaches, HR managers in corporations, trainers) $-56 \%$.

In order to identify preventive measures aimed at reducing the risk of occurrence of emotional competence gaps of successors, experts were presented with 10 preventive measures ${ }^{2}$ and 7 emotional competence gaps of successors (Dźwigoł-Barosz, 2017, p. 74-82) (Figure 4). A method of individual in-depths interviews allowed the experts to present preventive measures other than the previously determined ones.

Figure 4. Competence gaps and preventive measures reducing

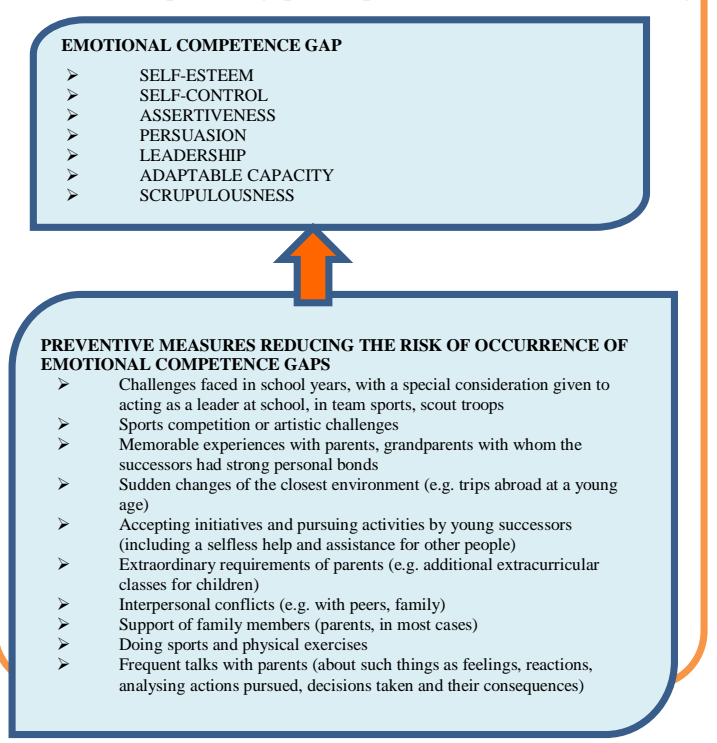

the risk of occurrence of competence gaps in terms of emotional intelligence. Own work.

The experts were asked to score each preventive measure with a mark, from 1 to 3 , where:

1 -low effectiveness of a preventive measure aimed at reducing the risk of the occurrence of a gap within the scope of a given competence group,

2 -average effectiveness of a preventive measure aimed at reducing the risk of the occurrence of a gap within the scope of a given competence group,

3 -high effectiveness of a preventive measure aimed at reducing the risk of the occurrence of a gap within the scope of a given competence group.
It was assumed that the most effective measure in terms of reducing the risk of the occurrence of an emotional competence gap is the preventive measure which was most frequently hailed by the experts as the most effective one.

The results of the empirical verification allowed to select the preventive measures that would reduce the risk of occurrence of emotional competence gaps. Table no. 1 shows competence gaps with preventive measures that were hailed by the experts as the most effective ones.

Table 1.

The most effective preventive measures reducing the risk of occurrence of emotional competence gaps

\begin{tabular}{|c|c|}
\hline $\begin{array}{c}\text { The Most Effective Preventive } \\
\text { Measure }\end{array}$ & Competence Gap \\
\hline $\begin{array}{l}\text { Challenges faced in school years, } \\
\text { with a special consideration given to } \\
\text { acting as a leader at school, in team } \\
\text { sports, scout troops }\end{array}$ & $\begin{array}{l}\text { Self-Esteem } \\
\text { Self-Control } \\
\text { Assertiveness } \\
\text { Persuasion } \\
\text { Leadership } \\
\text { Adaptable Capacity } \\
\text { Scrupulousness }\end{array}$ \\
\hline $\begin{array}{l}\text { Sports competition or artistic } \\
\text { challenges }\end{array}$ & $\begin{array}{l}\text { Self-Esteem } \\
\text { Self-Control } \\
\text { Leadership } \\
\text { Adaptable Capacity } \\
\text { Scrupulousness }\end{array}$ \\
\hline $\begin{array}{l}\text { Memorable experiences with parents, } \\
\text { grandparents with whom the } \\
\text { successors had strong personal bonds }\end{array}$ & - \\
\hline $\begin{array}{l}\text { Sudden changes of the closest } \\
\text { environment (e.g. trips abroad at a } \\
\text { young age) }\end{array}$ & $\begin{array}{l}\text { Self-Esteem } \\
\text { Self-Control } \\
\text { Leadership } \\
\text { Adaptable Capacity }\end{array}$ \\
\hline $\begin{array}{l}\text { Accepting initiatives and pursuing } \\
\text { activities by young successors } \\
\text { (including a selfless help and } \\
\text { assistance for other people) }\end{array}$ & $\begin{array}{l}\text { Self-Esteem } \\
\text { Self-Control } \\
\text { Persuasion } \\
\text { Leadership } \\
\text { Adaptable Capacity } \\
\text { Scrupulousness }\end{array}$ \\
\hline $\begin{array}{l}\text { Stringent requirements of parents } \\
\text { (e.g. additional extracurricular classes } \\
\text { for successors) }\end{array}$ & $\begin{array}{l}\text { Self-esteem } \\
\text { Self-control } \\
\text { Persuasion } \\
\text { Adaptable Capacity } \\
\text { Scrupulousness }\end{array}$ \\
\hline $\begin{array}{l}\text { Interpersonal conflicts (e.g. with } \\
\text { peers, family) }\end{array}$ & $\begin{array}{l}\text { Self-Control } \\
\text { Assertiveness } \\
\text { Persuasion } \\
\text { Leadership } \\
\text { Adaptable capacity }\end{array}$ \\
\hline $\begin{array}{l}\text { Support of family members (parents, } \\
\text { in most cases) }\end{array}$ & $\begin{array}{l}\text { Self-Esteem } \\
\text { Self-Control } \\
\text { Assertiveness } \\
\text { Leadership } \\
\text { Adaptable Capacity } \\
\text { Scrupulousness }\end{array}$ \\
\hline Doing sports and physical exercises & $\begin{array}{l}\text { Self-Esteem } \\
\text { Self-Control } \\
\text { Leadership } \\
\end{array}$ \\
\hline $\begin{array}{l}\text { Frequent talks with parents (about } \\
\text { such things as feelings, reactions, } \\
\text { analysing actions pursued, decisions } \\
\text { taken and their consequences) }\end{array}$ & $\begin{array}{l}\text { Self-Esteem } \\
\text { Self-Control } \\
\text { Assertiveness } \\
\text { Persuasion } \\
\text { Leadership } \\
\text { Adaptable Capacity } \\
\text { Scrupulousness }\end{array}$ \\
\hline
\end{tabular}

Note: own work

Upon the analysis of the research findings, it was underlined that two preventive measures had been hailed by experts as the most effective ones in the process of reducing the risk of occurrence of emotional competence gaps within the scope of seven areas where the said gaps were identified.

The measures are the following:

- challenges faced in school years, with a special consideration given to acting as a leader at school, in team sports, scout troops; 
- frequent talks with parents (about such things as feelings, reactions, analysing actions pursued, decisions taken and their consequences).

It might be therefore assumed that the above-mentioned preventive actions can be applied as the most favourable methods in the process of reducing the risk of occurrence of emotional competence gaps.

The support of family members (parents, in most cases), as well as promoting initiatives and pursuing activities by young successors (including a selfless help and assistance for other people) are also widely applied as preventive measures. The methods were highly effective in terms of as many as six competence gaps, where five gaps referred to the same areas of competencies.

The risk of occurrence of emotional competence gaps in terms of self-esteem, self-control, leadership and adaptable capacities can be reduced, in the view of experts, through sports competition or artistic challenges, as well as sudden changes of the closest environment (e.g. trips abroad at a young age). In terms of sports competition or artistic challenges, the said method was also applied as a preventive measure reducing the risk of occurrence of diligence-related gaps.

Extraordinary requirements of parents towards their successors (e.g. extra curriculum classes) reduce the risk of occurrence of gaps in terms of: self-esteem, self-control, persuasion, adaptable capacities and scrupulousness, whereas interpersonal conflicts (with peers, family members) - in terms of: self-control, assertiveness, persuasion, leadership and adaptable capacities.

The most effective preventive measure in terms of self-esteem, self-control and leadership is, according to experts, doing sports and physical exercises.

Memorable experiences with parents, grandparents with whom the successors had strong personal bonds were not applicable, in the experts' opinion, as a preventive measure reducing the risk of occurrence of emotional competence gaps.

\section{Conclusion}

The global economy is based largely on family enterprises, which gives these entities a special role in the development of domestic and global economies.

The process of succession is an inseparable element of family enterprises, and the decision to start it is not often a simple issue, because it involves the transfer of power, knowledge, responsibility and management. This forces future managers to have specific competencies that determine the continuity of management and the survival of a family business, which should include not only economic aspects but also broadly understood interpersonal relationships.

Therefore, it is necessary to prepare the process of succession, taking into account the special role of the family seniors in the process of preparing successors from the youngest childhood, through gradual introduction of them into family business while transferring knowledge and practice and motivating selfdevelopment. If parents want their businesses to be taken over by next generations, they should think about the implementation the educational project (including emotional intelligence) for their successors.

The author's own research confirmed that preventive actions, destined to reduce the occurrence of the emotional competence gaps of successors, were widely applied. A particular emphasis should be put on two events: challenges faced in school years, with a special consideration given to acting as a leader at school, in team sports, scout troops, as well as frequent talks with parents. The said talks, in the experts' opinion, may be applied as a method to reduce all seven competence gaps. Thus, they can be treated as the most favourable method in the research in question.

\section{References}

i. Bennis, W.G., and Thomas R.J. (2002). Crucibles of Leadership. Harvard Business Review.

ii. Bieniok, H. (2007). Kształtowanie postaw przedsiębiorczych młodzieży w rodzinie, szkole i uczelni. W. Wachowiak, P., Dąbrowski, M., Majewski B. (Eds.). Ksztattowanie postaw przedsiębiorczych a 
Preventive Measures Reducing the Risk of Occurrence of

Competence Gaps in Terms Of Emotional Intelligence of Successors in Family Businesses in PolandCountries Mariola DŹWIGOŁ-BAROSZ, PhD

Goodyear Publishing Co., Santa Monica 1978; „Promoting Emotional Competence in School-Aged Children: The Effects of the PATHS Curriculum", Development and Psychopathology 7 (1995); W.G. Bennis, R.J. Thomas: Crucibles of Leadership, Harvard Business Review, September 2002; H. Bieniok: Kształtowanie postaw przedsiębiorczych młodzieży w rodzinie, szkole i uczelni [w:] P. Wachowiak, M. Dąbrowski, B. Majewski (red.), Ksztaltowanie postaw przedsiębiorczych a edukacja ekonomiczna, Fundacja Promocji i Akredytacji Kierunków Ekonomicznych, Warszawa 2007. 